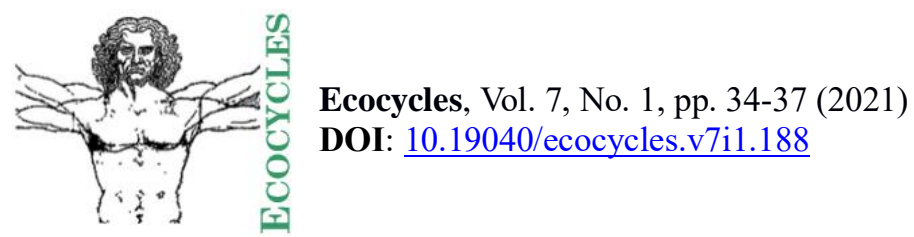

\title{
A review of the book' The Chemical Age. How Chemists Fought Famine and Disease, Killed Millions, and Changed Our Relationship with the Earth' by Frank A. von Hippel
}

\author{
András Székács \\ Institute of Environmental Sciences, Hungarian University of Agriculture and Life Sciences \\ szekacs.andras@uni-mate.hu
}

\begin{abstract}
This paper summarizes the views of the author on the new book 'The Chemical Age. How Chemists Fought Famine and Disease, Killed Millions, and Changed Our Relationship with the Earth' by Frank A. von Hippel.
\end{abstract}

Keywords - human and plant pathogens, pesticides, insecticides, warfare agents, humanitarian and environmental consequences, ethics

Retrospective books may have three main emphases: historism, continuity, or futurism. The main objective of the first approach is to make a timestamp; to erect a monument for the events that have taken place, so that those achievements will not go forgotten or unappreciated. The third approach looks into the future and views past events in the context of how they affect our immediate future or current deeds leading to our future. The second approach, in between, is a combination of the above two; nourishing our past with a view on the forthcomings that shape our future. Such categorization is, obviously, always subjective, yet let the reader be allowed such subjectivity. Both writing and reading of books are, after all, lonely activities, conveying personal intentions to express views or being based on personal comprehensions while being exposed to thoughts of the author.

With the above points raised, the book by Frank A. von Hippel, professor of environmental health sciences at the Mel \& Enid Zuckerman College of Public Health of the University of Arizona, appears to fall mostly into the first, but practically into all three of the above categories. It summarizes heroic past achievements in the use of chemical substances to fight human and plant pathogens causing deaths by disease or famine; it links these achievements to current day actualities; and it certainly doesn't lack allusions to the future, including its dedication for the next generation.
Right at the beginning, the author describes as a particularly shocking example of commitment to development how Thomas Midgley Jr., inventor of fluorotrichlorometane or Freon as a refrigerant gas in 1930 inhaled it to show its unharmful features in front of an audience. Such a demonstration would currently be considered a human experiment, and would therefore be strictly forbidden by ethical concerns. Or wouldn't it?

The author states very early on to the reader that chemical inventions can be, and frequently are having two contrasting aspects: the achievement in a given direction may, and often does result in unforeseen detrimental side-effects. And the illustration for that is not only the above ill-reputed case of Midgley but is particularly emphasized in connection to the indiscriminate use of pesticides. And should biologicalecological consequences not be enough, von Hippel also demonstrates how inventions of bioactive substances are utilized in "genocide, famine, and world wars".

This book is a collection and cultural-historical description of efforts against various pests and disease causative agents or vectors. The compilation is far not comprehensive; the examples are set by personal choice the background "rational" of which being revealed in the Epilogue. Nonetheless, the range of examples presented is broad and fully coherent, with a good reason as we learn it at the end. 


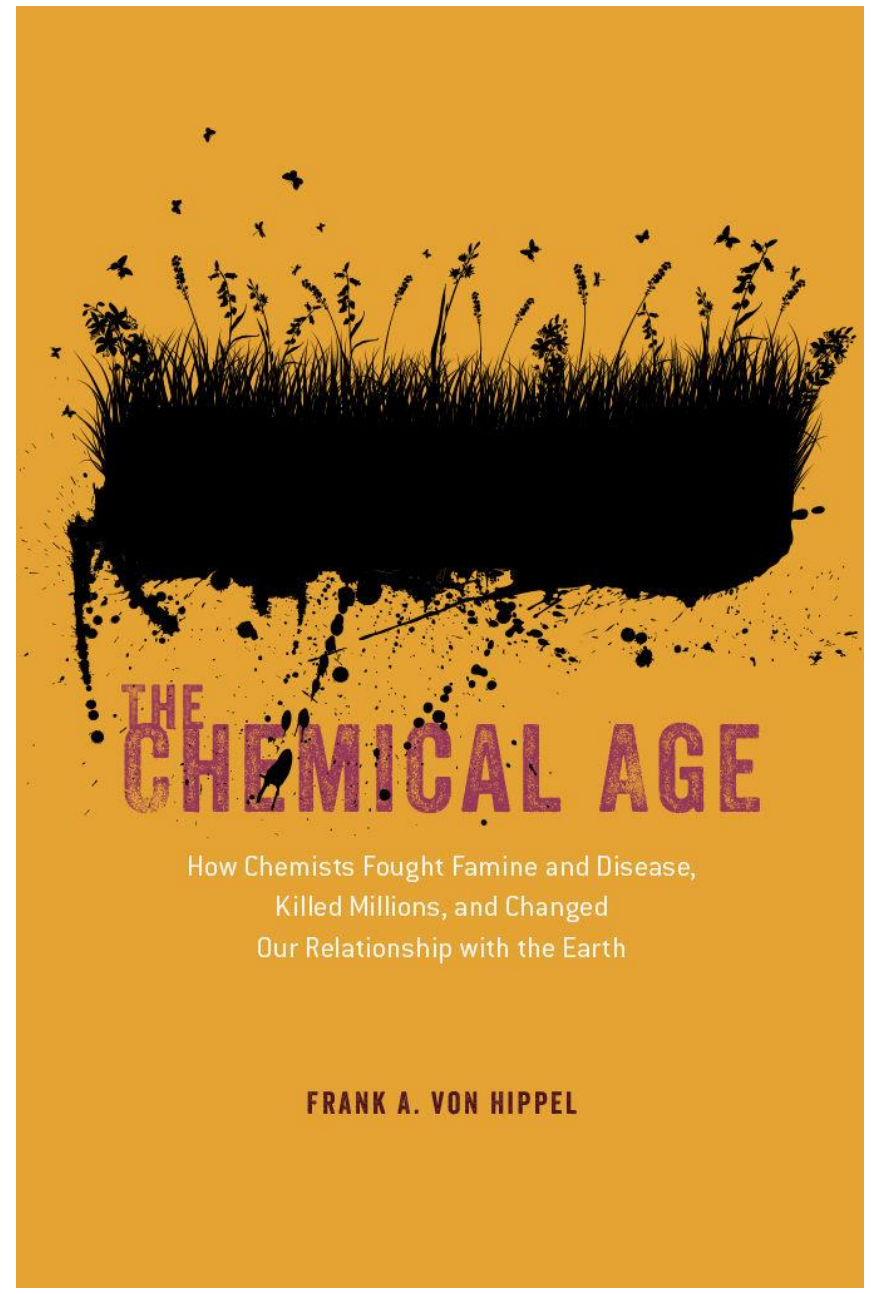

Title page of 'The Chemical Age. How Chemists Fought Famine and Disease, Killed Millions, and Changed Our Relationship with the Earth' by Frank A. von Hippel.

Reading the numerous cases of the discovery of the various bioactive chemical agents engrosses the attention not only of chemists, as story-telling by von Hippel includes ample cultural and historical aspects, linking the subject to literary examples or to well (or not so well) known events in history. The compounds or active ingredients themselves are not particularly discussed by their chemical aspects (not a single chemical structure is shown); the emphasis is rather on the invention during their discovery, the historical background and drives for their exploration, intentions in their development, costs of their unanticipated side-effects, their consequences on history; all in all up- and downwards aspects of human culture and civilization.

The book consists of four parts (each containing one or more chapters): two dealing with outstanding plant or animal (human) diseases, sources of striking famines and mass mortality; one depicting how the history of chemical pesticides and warfare agents are interwoven with each other; and one describing the biological and ecological consequences of a freewheeling release of pesticides into the environment. This is followed by a very much personal Epilogue.
The first two parts can be considered as an epic story of pathogen microbiology with detailed narratives on steps in the identification of the pathogens, competing or confronting directions in research approaches, turmoils caused by local or large-scale conflicts, cultural or societal controversies, wars or other political tensions. It is started with Phytophtora infestans leading to the sorrowful Irish Potato Famine in 1845-1846, and with the Mash fever, malaria, in which mosquitoes were identified as spreading vectors as late as in 1876. Similarly in-depth discussed stories follow on other worldwide epidemics, the yellow fever (not to be confounded with malaria), typhus, and the black plague, transmitted by mosquitoes, mites, and fleas, respectively. While discussing the discovery of these diseases, von Hippel touches on questions in fundamental biology, including the theory of spontaneous generation along with its experimental falsification, the theory of evolution and its implications, as well as their contiguity with famine. In addition, he also touches on the findings of various substances of natural origin of semi-synthetic nature for treating these diseases or controlling their vectors. The nicety of the embedding of these details of science history in the general context of the history of mankind makes an impression on the reader as if the author were a historian, not a natural scientist. Certain chronicles occasionally appear to be somewhat US-focused, but the overall picture is certainty global and balanced. A comment on a slight correction related to science history: the mention of the Wöhler synthesis is still a common misquotation as the first proof of the vis vitalis theory, like in this book, as by the time of Wölher's work Kolbe had already converted an inorganic substance, carbon disulfide, into an organic one, acetic acid (Ramberg, 2015).

The next two parts, dealing with military applications and environmental consequences of bioactive substances developed, are far less glorious, and trigger much more distress in the reader than the previous ones. Not unconnectedly, these are the most mind-boggling, thoughtprovoking parts of the book. The obvious fact that achievements in knowledge in chemistry can also very efficiently advance chemical warfare, presented here, is rather disillusioning. Although von Hippel, with good historian accuracy, mentions that fumes of sulphur and other chemical agents were yet rejected in the mid 19th century for not being in accordance "with the feelings and principles of civilized warfare", such "ethical" considerations have been shamefully abandoned in the on-coming century, giving rise to "modern chemical warfare" and to genocide.

By the end of World War I, not only chlorine but phosgene, mustard gas (bis(2-chloroethyl) sulphide), and a number of other irritant and highly toxic compounds were available as military attack gases. One recognizes with disappointment how intensely chemical warfare boosted the chemical industry in Germany and even more in the US. As the war ended, military attack gases were tamed, and the available industrial capacities were converted to pesticide production. This is the sad link between pesticides and chemical weapons, showing itself again after World War II that is woefully emphasized by von Hippel in this segment: the development 
of military chemicals gave birth to the first synthetic organic pesticides and boosted their further advancement after 1945. The chemical technology of nitrogen fixation produced fertilizers to start the Green Revolution, but also made the synthesis of an ample number of compounds designed to most effectively kill humans possible. This is portrayed by von Hippel by unvarnished frankness. The efforts to control agricultural pests have also often been, and still are, portrayed as a war against pests.

The product with the most evil memory of the development of warfare agents from insecticides is Zyklon B, hydrocyanic acid, which was intended for public health application against typhus but gained again mass homicidal significance in the concentration camps of the Nazi Third Reich. The world's most famous insecticide DDT (Gesarol, Neocid) also had a military significance, although indirect, on both sides of World War II, the Allies, and to a less but substantial extent Germany. More than that can be said about the chemical class of organophosphate insecticides. The development of these was personified by the I. G. Farben chemist Gerhard Schrader, whose early invention of the compounds tabun (ethyl N,N-dimethylphosphoramido-cyanidate) and sarin (propan-2-yl methylphosphono-fluoridate) were developed into warfare nerve poisons, and who screened hundreds of compounds as war gas candidates. Although these agents have not been deployed in military actions by the Wehrmacht (Everts, 2016), tabun and a range of other chemicals, not necessarily all for warfare use, were produced by concentration camp prisoners as slave workers of I. G. Farben; also recounted expressively by the Holocaust survivor Italian chemist and writer Primo Levi (Levi, 1947). It is particularly diabolic in this plot to have such warfare agents manufactured by the enslaved victims of the Nazi regime. And another wicked historical twist, shared by the book, is that the tabun factory has been transferred after the war by the Red Army to the Soviet Union, where it was reassembled to operate near Stalingrad (von Hippel, 2020).

Schrader certainly was a talented chemist who applied his intellect to the development of anti-insect agents, war gases, and then insecticides again. After the war, top executives of I. G. Farben were put on trial for war crimes and crimes against humanity at Nürnberg, but all possible charges against Schrader were dropped before the trial, in 1946 (Tucker, 2007). He continued his work as an insecticide chemist and developed several organophosphate insecticides, including parathion, malathion, and OMPA as the most famous ones (the latter later renamed schradan to his honour). He retired as the leader of the plant protection laboratory of Bayer (a former subsidiary of I. G. Farben) and a renowned pesticide chemist.

Part 4 of the book discusses in detail the environmental concerns related to the irresponsible use of pesticides: pest resistance and environmental consequences. These two chapters are, after all, thoroughgoing descriptions of the life, explorations, and achievements of Rachel Carson, leading to the birth of her legendary book, Silent Spring (Carson, 1962) and beyond. The astonishing accomplishment by this timid but utterly devoted woman is probably the most recognized triumph in successfully raising attention to the significance of detrimental environmental side-effects of pesticides, having a major impact on current day pesticide regulation. Nonetheless, reading the detailed events related to her work is rather informative, in some cases enlightening to the reader. The following chapter "Wonder and Humility" is supposed to address our changed relationship with the Earth, a major objective of the book promised in its subtitle. Indeed, it touches upon food poisoning by polychlorinated hydrocarbon and organophosphate type insecticides, upon the teratogenic action of polychloro-dibenzodioxins related to phenoxyacetic acid type herbicides and again to military applications. Particularly interesting are the various steps, described by the author, taken during the Vietnam War to stop or limit the use of biological or chemical weapons. As for insecticides beyond chlorinated hydrocarbons and organophosphates, the author briefly mentions pyrethroids and neonicotinoids, but does not elaborate much on these substances. Similarly, he mentions endocrine disruption, as an emerging concern for unforeseen side-effects of pesticides (and other chemicals). In this context, at least the pioneering book Our Stolen Future by Theo Colborn, Dianne Dumanoski, and John Peterson Myers (Colborn et al. 1996) should have been cited.

Nonetheless, the promise of showing our changed relationship with the Earth is not fulfilled in the last part with similar rigor as the monument is erected for historic achievements (or crimes) in the previous ones. Unforeseen biological effects of those agents on wildlife and humans, including mutagenicity, endocrine disruption, and immunomodulation need to be covered if one attempts to provide a comprehensive picture. The lack of legal definitions and measures to effectively enforce protection against such effects is sadly not raised in the book. If neonicotinoids are mentioned, legal steps taken for restrictions of their use or for their withdrawal (Butler, 2018) should have been mentioned, just like the issue of the excessive use of seed coating for prophylaxis, resulting in increased environmental exposures also in cases when the occurrence of the target pests doesn't take place (van der Sluijs et al. 2015). And if the (ab)uses of pesticides or related compounds in military activities are discussed, the use of the herbicide active ingredient glyphosate in the drug war could have also been covered, just as the current excessive use of glyphosate boosted by the cultivation of glyphosate-tolerant genetically modified crops. Talking about gene technologies, and as mosquitoes are discussed in detail as transmitting vectors of not one of the epidemics mentioned in the book, the vast environmental risks of the proposed use of gene drive technologies for mosquito eradication would also have been merited being mentioned.

The last segment of the book, not labelled as a Part, is an Epilogue, revealing some of the family history of the author, being the great-grandson of the Nobel Laureate German physicist James Franck. Meanwhile, before reading this chapter the reader could have a feeling of lack in the range and subjectivity in the choice of topics covered in the book, all this falls in place when reading the family antecedents of 
the author here: glory in achievements and also calamities and hardships, including an unbidden resignation from office driven by conscience due to the inhumanity of the Nazi legal regulations as well as a corresponding forced immigration of the family, were entangled in the turmoil of the spectacular successes in theoretical and applied physics as well as synthetic chemistry in Germany during the turn to the 20th century and then the breakout of two horrible world wars and times that tried people's souls. With all this, both laurels or trouble accented in the Epilogue considered, it is straightforward for the reader why the author chose these particular subject matters. I would also add, it might have been quite a task for the author being born in this family with such a rich history to handle the family tradition in his work, which he admirably achieved.

As seen from the above, beyond a thematic retrospection, von Hippel raises numerous ethical questions. The main one of these is the responsibility of the inventor towards the application and future consequences of the product she/he developed. This applies equally to our cultural ethics (crimes against mankind committed) or environmental ethics (harms on the global ecology and the environment). As for the first one, the reader can contemplate the statement von Hippel attributes to Fritz Haber: "A scientist works for the world during peaceful times but for his country during war times". The ethical complexity beyond this simplistic statement is excellently illustrated by the very example of James Franck opposing the use of the atomic bomb, told about by the author. Considering the current status of our ecosystem, similarly important questions are how much we can allow ourselves to "master" nature, what hazards can be dumped on our environment, what benefits are worth what risks of potentially irrecoverable harms.

With the above in mind, one can arrive at the conclusion that the book The Chemical Age by Frank A. von Hippel is a rich source of information on human inventions related to the fight against diseases and hunger, as well as a thought-provoking compilation of issues emphasizing the great need for humanitarian and environmental ethics. Several additional issues, mentioned above, would have also been welcome to be discussed, but the personal choice of the author can easily be understood by reading his history and family background. One can only hope that he will cover those missing topics, including the burning issues of endocrine disruption or immunomodulation, also falling into his research interests, in a possible next volume of the book.

\section{REFERENCES}

Butler, D. (2018): Scientists hail European ban on beeharming pesticides. Nature 27 April 2018.

DOI: $10.1038 / \mathrm{d} 41586-018-04987-4$

Carson, R. (1962): Silent Spring. Houghton Mifflin Co., Boston, MS, USA.

Colborn, T., Dumanoski, D., Peterson Myers, J. (1996): Our Stolen Future: Are We Threatening Our Fertility, Intelligence, and Survival? A Scientific Detective Story. Dutton, New York, USA

Everts, S. (2016): The Nazi origins of deadly nerve gases. Chem. Eng. News 94 (41): 26-28.

Levi, P. (1947): Se questo è un uomo. Einaudi, Torino, Italy.

Ramberg, P. J. (2015): Myth 7. That Friedrich Wöhler's Synthesis of Urea in 1828 Destroyed Vitalism and Gave Rise to Organic Chemistry. In: Newton's Apple and Other Myths About Science. (Numbers, R. L., and Kampourakis, K., Eds.) Harvard University Press, Cambridge, MS, USA. pp. 59-66. DOI: $\underline{10.4159 / 9780674089167-009}$

Tucker, J. R. (2007): War on Nerves: Chemical Warfare from Worlds War I to Al-Qaeda. Anchor Books, New York, USA.

van der Sluijs, J. P., Amaral-Rogers, V., Belzunces, L. P., Bijleveld van Lexmond, M. F. I. J. M. F. I. J., Bonmatin, JM., Chagnon, M., Downs, C. A., Furlan, L., Gibbons, D. W., Giorio, C., Girolami, V., Goulson, D., Kreutzweiser, D. P., Krupke, C., Liess, M., Long, E., McField, M., Mineau, P., Mitchell, E. A. D., Morrissey, C. A., Noome, D. A., Pisa, L., Settele, J., Simon-Delso, N., Stark, J. D., Tapparo, A., Van Dyck, H., van Praagh, J., Whitehorn, P. R., Wiemers, M. (2015): Conclusions of the Worldwide Integrated Assessment on the risks of neonicotinoids and fipronil to biodiversity and ecosystem functioning. Environ. Sci. Pollut. Res. 22(1):148154.

DOI: $10.1007 / \mathrm{s} 11356-014-3229-5$

von Hippel (2020) The Chemical Age. How Chemists Fought Famine and Disease, Killed Millions, and Changed Our Relationship with the Earth. The University of Chicago Press, Chicago, US. p. 199.

(C) 2021 by the author(s). This article is an open-access article distributed under the terms and conditions of the Creative Commons Attribution (CC BY) license (http://creativecommons.org/licenses/by/4.0/). 